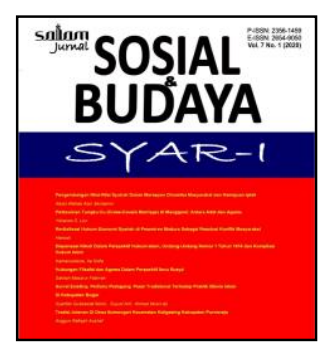

\title{
The Islamic Studies and the Study of Religions by the Early Indonesian Muslim Scholars*
}

\author{
Alfina Hidayah, ${ }^{1}$ Hamdan Maghribi ${ }^{2}$ \\ Institut Agama Islam Negeri Surakarta
}

do

$10.15408 /$ sjsbs.v8i3.19910

\begin{abstract}
This research is an effort to raise the development of religious studies (Islamic Studies) and the study of religions that already emerged and developed in the archipelago before twentieth century. This can be known through the figures of previous Muslim scholars and their works on these topics. The research process uses qualitative methods on a literature review which will be delivered descriptively. While the aim of research is to find out how the Muslim scholars of Indonesian Archipelago have contributed in various aspects particularly in the field of knowledge and intellectual supported by their extraordinary works in the form of books, poem, etc. As a manifestation of their role in da'wah in addition to enrich the scientific treasures. So it can be concluded in a broad outline that additionally to the Nine Saints (Wali Sanga), the archipelago has Muslim scholars who have taken part in Islamic preaching and furthermore they explored their teachings into wonderful works, both on Islamic (religious) studies as well as the study of religions.
\end{abstract}

Keywords: Islamic Studies, Study of Religions, Indonesian Muslim Scholar

\begin{abstract}
Abstrak
Penelitian ini adalah upaya untuk mengangkat tentang perkembangan kajian keagamaan (Islam) maupun studi tentang agama-agama yang telah lama muncul dan berkembang di Nusantara sebelum abad 20. Hal tersebut dapat diketahui melalui tokoh-tokoh ulama muslim terdahulu beserta karya-karya mereka yang mengkaji tema-tema tersebut. Proses penelitian ini menggunakan metode kualitatif dan juga merupakan kajian pustaka yang akan disampaikan secara deskriptif. Adapun tujuan penelitian untuk mengetahui bagaimana ulama muslim Nusantara telah berkontribusi dalam berbagai aspek dan salah satu nya adalah secara intelektual mereka melahirkan karya-karya luar biasa baik berupa buku, puisi, dsb sebagai wujud dari peran dakwah sekaligus memperkaya khazanah keilmuan. Sehingga dapat disimpulkan secara garis besar bahwa selain para Wali Sembilan (Wali Sanga), Nusantara memiliki ulama-ulama muslim yang telah banyak berkiprah dalam berdakwah serta menuliskan pokok-pokok ajarannya dalam karya-karya mereka, baik tentang kajian keislaman juga kajian agama-agama.
\end{abstract}

Kata Kunci: Kajian Islam, Kajian Agama-Agama, Ulama Muslim Nusantara

*Received: May 23, 2021, Revision: May 26, 2021, Published: June 5, 2021.

${ }^{1}$ Alfina Hidayah is a lecturer of Aqidah and Islamic Philosophy, FUD IAIN Surakarta. E-mail: alfina.hidayah@iain-surakarta.ac.id

${ }^{2}$ Hamdan Maghribi is a lecturer of History and Civilization of Islam, FAB IAIN Surakarta. E-mail: hamdan.maghribi@iain-surakarta.ac.id 


\section{A. INTRODUCTION}

Colin Brown in his book 'A Short History of Indonesia' mentioned the word 'Indonesia' began to be discussed in the period (mid-nineteenth century CE), in which it contained several meanings for its geographical, political and social implications. Its geographical meaning as the controversial one, unlike its social and political implications. ${ }^{3}$ Besides, James Richardson pointed that the word 'Indonesia' referred back to its various archipelagos called 'Nusantara', the word used for the Indonesian territories before the establishment of the state in the early twentieth century CE. 'Nusantara' the collective islands of Indonesia also used in the 'Nagarakrtagama' (the lengthy panegyric poem in old Javanese language) for the outer islands of Java. By then, the word had revived in the twentieth century $\mathrm{CE}$ as a poetic name for the Indonesian archipelago. ${ }^{4}$

Since this study emphasized on the the development and the works of Islamic study and the study of religions by the muslim scholars before the establishment of the country recently named Indonesia, hence an author used to entitled the Indonesian archipelago. Whereas indicated the ages approximately before twentieth century CE Indonesia.

As worldly known, the ancient Indonesia consisted of various kingdoms had established in assorted places; Sumatra, Java, Kalimantan (Borneo), Sulawesi (Celebes), and the Eastern islands of Indonesia. The establishment of Islamic kingdoms emerged in the fifteenth century CE onwards. Whereas the Islamic teaching was also taught to the state by some particular muslim scholars and mostly by the Sufis. Some of these people were considered noble men among the society such as the nine saints (Wali Sanga) or often translated by The Sangha of Saints; Maulana Malik Ibrahim, Sunan Ampel, Sunan Giri, Sunan Bonang, Sunan Drajat, Sunan Kudus, Sunan Kalijaga, Sunan Muria and Sunan Gunung Jati. In addition to them, the other well-known Saints were also mentioned in the history for examples Syekh Jumadil Kubro, Sunan Sitijenar, Sunan Walilanang, Sunan Bayat, and Sunan Ngudung, though this article will not concern on the teaching of these Sunans.

Instead of that, this mainly work will discuss the growth of Islamic studies and the study of religions in the hand of early muslim scholars in Indonesian archipelago which notably started from the seventeenth century CE to nineteenth century CE, since the muslim scholars in between fifteenth to sixteenth century CE were mostly among the nine Saints and the muslim Sultans. The description of early muslim scholars were along with their works such as books, poems, etc which representated their preaching on Islamic or religious teaching, especially intended to the people of their eras. As al-Attas stated that they introduced not only religious teachings to the local communities at

${ }^{3}$ Colin Brown, A Short History of Indonesia: The Unlikely Nation? (New South Wales: Allen \& Unwin, 2003), 2.

${ }^{4}$ Robert Cribb and Audrey Kahin, Historical Dictionary of Indonesia, second. (Maryland: Scarecrow Press, Inc., 2004), 301. 
archipelago but also introduced the rational thoughts in the form of philosophy, either the Islamic philosophy or the Greek philosophy. ${ }^{5}$

\section{B. METHODS}

This study is classified as literature or literature research, hence the author used a qualitative approach which produced a descriptive data. Besides, the research is quite holistic by emphasizing the study of complex systems. Systems are approached as coherent wholes whose component parts are best understood in context and in relation to one another and to the whole. In another word, comprehension of the parts of something as intimately interconnected and explicable only by reference to the whole. Here for instance, the explanation of contribution of the muslim scholars in the field of knowledge particularly regarding islamic teaching and the study of religions through their magnificent works as the outlines.

\section{RESULTS AND DISCUSSION}

\section{The Development of Islamic Studies}

The muslims role in the field of knowledge before twentieth century CE was referred back to the muslim educational institutions around sixteenth century CE called 'Pesantren', literally this word derived from 'Santri' simply means devout muslim, thus 'Pesantren' means living place for the Santris. ${ }^{6}$ The word of Pesantren is also commonly used with the addition of 'pondok' whereas derived from Arabic language 'funduq' means hotel, although it indicated an establishment providing shelter including meals and place to stay.

The 'pondok pesantren' consisted of firstly the domicile of Muslim scholar called 'kyai' having at least some knowledge on theology, Islamic laws, and Sufism. The second component was the Mosque where kyai and the santris/students performed their prayers and some religious activities, the third condition was the place or any residential facility where the santris lived. ${ }^{7}$ In the beginning, the pesantrens were built generally for the practice of Sufism by adult santris, although it does not necessarily follow any particular Sufis order, but nowadays it is intended for performing gathering prayers, religious studies and more often to perform Dzikir and Wirid. The existence of religious

${ }^{5}$ Syed Muhammad Naquib Al-Attas, Islam Dalam Sejarah Dan Kebudayaan Melayu (Kuala Lumpur: ABIM, 1972), 31.

${ }^{6}$ Ronald Lukens-Bull, A Peaceful Jihad: Negotiating Identity and Modernity in Muslim Java (New York: Palgrave Macmillan, 2005); See: Zamakhsyari Dhofier, “The Pesantren Tradition: A Study of the Role of the Kyai in the Maintenance of the Traditional Ideology of Islam in Java" (The Australian National University, 1980).

${ }^{7}$ See: Julia Day Howell, "Sufism and the Indonesian: Islamic Revival," The Journal of Asian Studies 60, no. 3 (2001): 704 . 
educational institution such pesantren in the sixteenth century Indonesia has signified that the practice of knowledge transformation has already set up in archipelago. ${ }^{8}$

Another indication of knowledge and Intellectual achievement in the preModern period Indonesia was the presence of great muslim scholars who were supported by the muslim Sultans, either originally the Indonesian descent or outsiders. On this field, their contributions were mostly in the study of Tasawuf(Islamic mysticism) in which they expounded the ideas and thought through several literary works.

On the contrary, the study of religions before twentieth century CE in Indonesia was not much attractive to the local muslim society, because the major concern of the muslim scholars was on religious preaching and Islamic teaching including Islamic law and Jurisprudence as well as mysticism were more widespread and acceptable. Since we identify the history of religious expansion, the Sufis were the significant actors in the spread of Islam in Indonesian archipelago. ${ }^{9}$ Some remarkable Indonesian muslim scholars on the study of religions were apparently from the seventeenth century CE as soon as the Islamic teachings laid its roots between the local peoples primarily since the Islamic kingdoms emerged over the archipelago.

\section{Early Muslim Scholars and Works on Religious Study}

Around seventeenth to nineteenth century CE, the muslims have participated a lot either in political, social and intellectual activities, perhaps it was noted since the establishment of Islamic kingdoms in several corners of the country. As a result of that, the muslims contributed and were involved in all aspects of life..$^{10}$

The first among them who paid his attention to knowledge was Hamzah Pansuri or Fansuri (d. 1527 CE), he was known as a poet who was born in the West Sumatran camphor of Barus (Fansur) and died in Mecca. He lived for sometime in Ayodhya in Siam and he also joined the Islamic mysticism țariqa of Wujūdiyyah in this city, he also ever spent his time in Baghdad. His famous poem was 'Sharab al-Ashiqin' (the Lovers' Beverage) and 'Asrār al-'Árifin' (the Secrets of the Gnostics) written in the reign of Iskandar Muda at Sumatra which latterly was criticized by Nuruddin al-Raniri by saying that this poem was dissent and heresy. ${ }^{11}$

While the other eminent Muslim scholars in Aceh after Fansuri were Syamsuddin of Pasai (d. 1630 CE) and 'Abd al-Rauf Singkil (1615-1693 CE), Syamsuddin was written on 'Nūr al-Daqa' 'iq' (Light on the subtleties') and became a notable work in the history of Indonesian Muslims before twentieth century CE which is now translated

8 Thomas Gibson, Islamic Narrative and Authority in Southeast Asia: From the 16th Century to the 21st Century (New York: Palgrave Macmillan, 2007), 1-2.

9 Sri Mulyati, "Sufism in Indonesia: An Analysis of Nawawi Al-Banteni's Salalim Al-Fudala'" (McGill University, 1992), 1, 5-6.

${ }^{10}$ K. S. Nathan and Muhammad Hashim Kamali, Islam in Southeast Asia: Political, Social, and Strategic Challenges for the 21st Century (Singapore: ISEAS, 2006), 15.

${ }^{11} \mathrm{Cribb}$ and Kahin, Historical Dictionary of Indonesia. 
into some ethnic Indonesian languages. ${ }^{12}$ While 'Abd al-Rauf b. Ali al-Jawi al-Fansuri alSingkili was born in 1615 CE, a major scholar in the Sultanate of Aceh, he wrote works

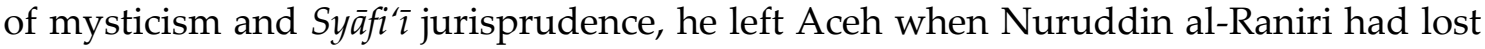
his favor in $1643 \mathrm{CE}$, then he spent eighteen years in Mecca and learnt from Ahmad Qushashi, then he returned back and introduced the Syattâriyyah tarīgah to Aceh in 1679 CE. ${ }^{13}$ During his return to Aceh, he completed the work of Nuruddin al-Raniri which was not complete yet when Nuruddin went back to India. This work entitled Jawähir al'Ulam fì Kasyf al-Ma'lūm was completed in 1665 CE and then he became a religious figure in region as Sheikh al-Islam. ${ }^{14}$ His major works were on the issue of law entitled Mir'at al-Ṭula $\bar{b}$ (the Mirror for the Seekers) finished in $1663 \mathrm{CE}$, he mainly talked about daily life affairs or mu'āmalāt. ${ }^{15}$

Sheikh Yusuf Makassar was another Muslim scholar of this century, he was born probably in $1626 \mathrm{CE}$ at Gowa of South Celebes (Sulawesi). His name was Abadin Tadia Tjoessoep (d. 1699 CE), more commonly known as Sheikh Yusuf of Makassar, was an Indonesian muslim of noble descent. In 1693 CE he was exiled to the Cape of Good Hope which resulted in his establishing Islam in the Cape. Makassar is the name after a town in Sulawesi of Indonesia. He who certified the Qädiriyyah țarīqa by his teacher Nuruddin al-Raniri as written in his work Safinah al-Najät (the ship of success), moreover he was also certified the Naqșābandi țarīqa by his teacher Sayed Sheikh Abi Abdullah Muhammad Abdul Baqi bin Sheikh al-Kabir Mazjaji al-Yamani Zaidi al-Naqshabandi in Yemen. He again licensed al-Ba'alawiyyah țarīa from his teacher Sheikh Maulana Sayed Ali, and then he went to Medina and was certified Syattäriyyah țariqa by Sheikh Ibrahim Hasan bin Shihabuddin al-Kurdi al-Kaurani or known as Mulla Ibrahim. He was not satisfied and went to Damascus, there he learnt from Sheikh Abu al-Barakat Ayyub bin Ahmad bin Ayyub al-Khalwati al-Qurashi whereas he was certified by Khalwātiyyah țarīqa and his teacher titled him Tāj al-Khalwāti Hadiyatullah.

Other than these five tarīqas, he also learnt the tarīqa of Dasūqiyyah, Syaziliyyah, Hašiyyah, Rifä'iyyah, al-Idrūsiyyah, Ahmādiyyah, Suhrāwardiyyah, Maulāwiyyah, Kubrāwiyyah, Madāriyyah, Makhdūniyyah, etc. ${ }^{16}$ Some of his notable works are: Kaifiyāt alMughnī wa al-Iśbāt, Safinah al-Najāt, Habl al-Wārid li Sa'ādāt al-Murīd, al-Barakāt alSailāniyyah, al-Nafḥah al-Sailāniyyah, Mațālib al-Sālikīn, Risālah Ghāyah al-Ikhtișār, these texts were written during his life in Ceylon. ${ }^{17}$ Owing to the fact that he was exiled to Ceylon and South Africa, he is also known as the early Muslim preacher in South Africa, he died there in $1699 \mathrm{CE}$ in 73 years old, and was buried in this city from where his grave was shifted to Makassar in 1705 CE. ${ }^{18}$ There are numerous writings of Sheikh Yusuf

12 M C Ricklefs, A History of Modern Indonesia since c. 1300-Present, 3rd ed. (London: Palgrave Macmillan, 1981), 60.

${ }^{13}$ Mulyati, "Sufism in Indonesia : An Analysis of Nawawi Al-Banteni's Salalim Al-Fudala'."

${ }^{14}$ Gibson, Islamic Narrative and Authority in Southeast Asia: From the 16th Century to the 21st Century.

${ }^{15}$ Amirul Hadi, Islam and State in Sumatra: A Study of Seventeenth-Century Aceh (Leiden: Brill, 2003),

205.

${ }^{16}$ Abu Hamid, Syekh Yusuf Makassar: Seorang Ulama, Sufi Dan Pejuang (Indonesia, Jakarta: Yayasan Obor Indonesia, 1994), 91-93.

${ }^{17}$ Hamid, Syekh Yusuf Makassar: Seorang Ulama, Sufi Dan Pejuang.

${ }^{18}$ Ibid. 
Makassar, and 29 of them were identified as his authentic works, while others were anonymous writings which were probably written by his followers as Sheikh's name was also sometimes mentioned perhaps as their source or reference. ${ }^{19}$

The Sammāniyyah appeared in Sumatra in the eighteenth century CE through another well known Muslim scholar 'Abd al-Samad ibn 'Abd Allah (d. 1800 CE), he was known as al-Palembangi, a name of a city where he came from. He studied at Mecca from Muhammad ibn 'Abd al-Karim al-Samman (1719-1775 CE), founder of the Sammāniyyah in Medina. 'Abd al-Samad of Palembang has various works on Islamic mysticism such as Sayr al-Sälikin, a translation and commentary on parts of al-Ghazali's Ihyā' 'Ulūm al-Dīn, Zuhrat al-Murīd fì Bayān Kalimāt al-Tauḥìd, Nașịhah al-Muslimīn wa Tażkirah al-Mu'minīn fì Faḍā'il al-Jihād fì Sabīl Allāh wa Karāmah al-Mujāhidīn fì Sabīl Allah completed in $1765 \mathrm{CE}$ which inspired against the Dutch colonialism at the time, Tuhfah al-Rāghibìn fì Bayān Haqūqah İmān al-Mu'minīn, al-'Urwa al-Mutqā wa Silsilah ūlì al-Ittiqā, Hidayah al-Sālikìn fì Sulūk Maslak al-Muttaqīn, and Zād al-Muttaqīn fì Tauhìd Rabb al'Álamin. ${ }^{20} \mathrm{He}$ wrote these works almost certainly between 1765-1778 CE in Aceh, while among his popular endeavor for the peoples of Aceh was 'Rātib Sammān' this text cited $\dot{Z} i k r .21$

Muhammad Nafis ibn Idris ibn Husayn al-Banjari known as Nafis al-Banjari was another scholar of the eighteenth century CE. He was an important Sufi who gave his influences to the South East Asian Muslims. He was born in Martapura of the Banjarmasin kingdom at South Kalimantan, the accurate date of his birth was unknown. His precious treatise al-Durr al-Nafis was written in 1786 CE. ${ }^{22}$ His treatise was considered very precious writing on Sufism of the time which was popular among the Muslims in Indonesia, Malaysia, Singapore, Philippine, and Thailand. It was written in Jawi (Malay) in Arabic script and was published several times in Southeast Asia and in the Middle East as well.

Basically the work contained four chapters; Tauhīd al-Af'āl (the unity of actions), Tauhìd al-Asma' (the unity of names), Tauhìd al-Sifät (the unity of attributes), and Tauhìd $a l-\dot{Z} \bar{a} t$ (the unity of essence) while in the conclusion he discussed on 'Ilm al-Lādunnì (the esoteric knowledge). ${ }^{23}$ Apparently his idea was much influenced by the Sammaniyyah Sufi masters 'Abd al-Karim al-Samman and Siddiq ibn 'Umar Khan and by other Sufi as Ibn 'Arabi. ${ }^{24}$

Abu 'Abd al-Mu'ti Muhammad ibn 'Umar ibn 'Arabi al-Tanari al-Bantani al-Jawi known as Nawawi al-Bantani was another scholar nineteenth century CE. Born in Banten of West Java in 1813 CE. His major works were presented in various branches of Islamic studies. He has written more than one hundreds works as noted by Rafi'u al-

\footnotetext{
${ }^{19} \mathrm{Ibid}$

${ }^{20}$ Mulyati, "Sufism in Indonesia : An Analysis of Nawawi Al-Banteni's Salalim Al-Fudala'."

${ }^{21}$ Ibid.

${ }^{22}$ Abdul Muthalib, "The Mystical Thought of Muhammad Nafis Al-Banjari: An Indonesian Sufi of the Eighteenth Century" (McGill University, 1995), 9.

${ }^{23}$ Muthalib, "The Mystical Thought of Muhammad Nafis Al-Banjari: An Indonesian Sufi of the

${ }^{24}$ Ibid.
} Eighteenth Century." 
Din Ramli and Chaidar. ${ }^{25}$ In the field of Tafsir, his major work was Marah Labid li Kasyf Ma'nā al-Qur'ān al-Majīd also known as al-Tafsīr al-Munìr li Ma'älim al-Tanzīl al-Musfir 'an Wujūh Mahāsin al-Ta'wīl published in Cairo $1305 \mathrm{H}$. in the field of Islamic Jurisprudence. He annotated the Fath al-Qarīb of Muhammad ibn al-Qasim al-Ghazzi and he also given a commentary on Abu Shuja' al-Isfahani's work al-Taqrīb, etc. in the field of Aqedah, he worked on several commentaries such as Żarī'ah al-Yaqīn, Nūr al-Zalām, Tijān al-Darārī, etc.

In the field of Islamic mysticism he wrote Salālīm al-Fuḍalā', Qāmi' al-Tughyān, Mișbāh al-Zulām, etc. Regarding the Seerah of Prophet Muhammad Peace be upon Him, he wrote Maulid al-Nabī, Bughyah al-'Awwām fì Syarh Maulid Sayyid al-Anām li ibn al-Jauzī, etc. in the field of Arabic grammar, he wrote Kasyfal-Murūtiyyah 'an Sitār al-Ajurūmiyyah, al-Fușūș al-Yaqūtiyyah, etc. In the field of rhetoric, he wrote Lubāb al-Bayān fì 'Ilm al-Bayān, and there are some other works done. ${ }^{26}$

Nawani al-Bantani was considered as the last commentator of the Quran of his generation, before the reformation brought by Jamal al-Din al-Afghani, Muhammad Abduh, and Rashid Rida as stated by Martin van Bruinessen. He further said that Nawawi's works were still used in about 42 pesantrens (traditional Islamic schools) in Indonesia although it also taught in religious schools in Mindanao (Southern Philippines), Thailand and Malaysia. His writings covered every aspects of Islamic learning and most of them were the commentaries on standard works in the sense that he attempted to explain in the simplest forms. ${ }^{27}$

\section{Early Muslim Scholars and Works on the Study of Religions}

While in the study of religions, Steenbrink noted that no work had been written on comparative religion before twentieth century $\mathrm{CE}$ other than the noteworthy work of Nuruddin al-Raniri (d. 1658 CE) of the seventeenth century CE, while others such as Ahmad Rijal al-Din and Munshi Abdullah were not considered as the scientific contribution in the study of religions since they were translators and informants for the British Government in Malay archipelago. Basically, these two scholars were mentioned the muslims and the Hindus as their objects of study during their visits to Calcutta, while it did not give significant information other than the bathing resort and brothels. Again Steenbrink argued that the Indonesian Muslims did a lot of traveling, despite that they did not write much particularly in the field of comparative religion as compared to the works of al-Biruni or Ibn Batuta when they afforded on the history of different religions and cultures. ${ }^{28}$

Among the early muslim scholars who worked on the study of religions in Indonesian Archipelago was Nuruddin Muhammad b. Ali b. Hasanji b. Muhammad

\footnotetext{
${ }^{25}$ Ibid.

${ }^{26}$ Ibid.

27 Ibid.

${ }^{28}$ Karel A Steenbrink, “The Study of Comparative Religion by Indonesian Muslims," Numen 37, no. 2 (1990): 145-146.
} 
Hamid al-Raniri, a Hadrami descent born in the city of Gujarat and according to some author he was probably belongs to a Malay mother. ${ }^{29}$ Within 1637-1644 CE he traveled to Islamic world and thus he came to Aceh during the reign of Sultan Iskandar Thani (1637-1641 CE), whereas the area was surrounded by the mystical ideas of Hamzah Fansuri and Syamsuddin of Pasai. Soon after, Nuruddin al-Raniri won the heart of Sultan Iskandar Thani who gave him a position of Sheikh al-Islam in the Sultanate of Aceh between 1637-1643 CE, then rapidly he banned and persecuted the followers of heresy brought by Hamzah Fansuri and Syamsuddin of Pasai as he thought their idea on pantheistic interpretation of Wahdat al-Wujüd was sort of heresy. He ordered to burn any heretical books. ${ }^{30}$

The life of Nuruddin al-Raniri was obviously qualified for the Islamic preaching particularly in the East Indies. He learnt at Mecca then traveled to some other Muslim countries for religious studies as well as preaching the Islamic laws according to Quran and Sunnah. While he arrived at Aceh around $1637 \mathrm{CE}$, that was a period of pantheistic mystical idea of Fansuri and Syamsuddin which taught in the region, thus he wrote 'the Proof of the Truthful in the Refutation of the Heretics' a polemical attack on the works of Hamzah Fansuri and Syamsuddin of Pasai. ${ }^{31}$ Furthermore, he made a great endeavor to guide the kingdom to Islamic monarchy and he compiled on instructional materials in Malay of several issues, especially regarding the Syar' $\bar{i}^{\prime} a h$ or Islamic law he wrote matters on Fasting, Muslim dietary laws, alms giving, the pilgrimage, and Jihad for the Acehnese students. ${ }^{32}$

In the favor of Sultan Iskandar Thani, Nuruddin wrote an encyclopedic work of Bustān al-Salāțīn (the Garden of the Kings). The work contained seven books including the story of creation, the prophets of Islam, the early Muslim Kings in the Middle East and the Malay kingdoms, the great and pious rulers, and the noble companions of the Prophet Muhammad Peace be upon Him. He also expounded the aptitude and several sciences for instance the Physiognomy and Medical science. ${ }^{33}$

According to al-Attas this book was the longest work ever written in Malay, ${ }^{34}$ while the first two books of the Bustān al-Salațin carried the history of the world, for instance the first mentioned the history of the Prophets including the story of the pen creation, the tablet, the light of Prophet Muhammad Peace be upon Him, etc. whereas the second book was written about the history of Persian, Greek, Arabian society before the coming of Islam, then history of Islam at length, year by year, which he ended his writing in the execution of al-Hallaj in $309 \mathrm{AH}$. This second book followed the tradition written by Tabari 'Annals' with addition of the Kings history of Indonesia/Malay and

${ }^{29}$ Gibson, Islamic Narrative and Authority in Southeast Asia: From the 16th Century to the 21st Century.

30 Abdul Aziz Dahlan, "Tasawuf Syamsuddin Sumatrani” (IAIN Syarif Hidayatullah, 1992); Ricklefs, A History of Modern Indonesia since c. 1300-Present.

${ }^{31}$ Gibson, Islamic Narrative and Authority in Southeast Asia: From the 16th Century to the 21st Century.

32 See: Amirul Hadi, Islam and State in Sumatra: A Study of Seventeenth-Century Aceh (Leiden: Brill, n.d.), 147-149.

${ }^{33}$ Ricklefs, A History of Modern Indonesia since c. 1300-Present.

${ }^{34}$ Gibson, Islamic Narrative and Authority in Southeast Asia: From the 16th Century to the 21st Century. 
India. The third book basically followed the work of al-Ghazali 'Nașinhah al-Mulūk $k^{35}$ as guidance for the kings. ${ }^{36}$

His contribution in the study of religions was partly written in Bustan al-Salatin which talked regarding the tracts against Jews and Christians, some arguments on Torah and Bible that both were considered as forgeries. ${ }^{37}$ In the second paragraph of the second book the death of Sabaa was discussed, child of Kiyamurti or Gayomart, according to Persian tradition he was the first man, in which Tabari envisaged a son of Adam. In the Tabari's historical harmonization of the Semitic Quranic and the Old Persian tradition, Kiyamurti/Gayomart was buried the corpse and put a light or probably a kind of candle beside the grave, perhaps this one of the reason that Majus worshipped fire.

In the explanation of Judaism, he did not mention any division of Jewish sects but he only brought the stories of the Prophets in very brief. Though he also mentioned the translation of Bible and the Septuagint in the Greek, while the story about Ezra and the way he found Torah was not mentioned. In spite of discussion on Christianity, he talked about Jesus as a prophet of Islam, the story about Zachariah who became the father of John, the story of John's execution, the story of God sending Jesus back to console his mother, and followed by the story of the sacking of Jerusalem by Titus. ${ }^{38}$

While essentially the study of religions has been elaborated to a great extent in his book al-Tibyān fì Ma'rifah al-Adyān, which has been written earlier by a great Muslim scholar al-Shahrastani in the book entitled Kitāb al-Milal wa al-Nihal, ${ }^{39}$ the other source Nuruddin has taken from Kitāb al-Tamhī ${ }^{40}$ by Abu Shakur al-Salimi. Nuruddin pursued the paths of al-Shahrastani in presenting the ideas of various religions other than Islam, first of all he discussed the world religions; the non revealed ones and the revealed one (Judaism and Christianity), in which he described Nestorians, Jacobinians and Melchionites as the three sects of Christianity founded by the three students of someone (fulan), a Jewish scholar, who was probably Paul, nevertheless his name was not mentioned. This work noted that Jesus was able to compile the whole contents of Torah through direct revelation from God, since the people did not believe him thus the prophet Ezra appeared and confirmed the text of Jesus. By then the devil said that both Ezra and Jesus were sons of God, as result the heresy flourished among the Christians. ${ }^{41}$ In the second part of the book, he elaborated the 72 sects of the Muslim Ummah, all of them deviated from the right path of the Sunni belief.

\footnotetext{
${ }_{35}$ Abū Ḥamid Al-Ghazālī, Al-Tibr Al-Masbūk Fi Nașīhat Al-Mulūk, ed. Aḥmad Syams al-Dīn (Beirut: Dār al-Kutub al-'Ilmiyyah, 1988).

${ }^{36}$ See: Michael Laffan, The Bustan Al-Salatin Nuruddin Ar-Raniri: Reflections on Cultural Role of Foreign Abroad in the Malay World in the Sixteenth Century (Leiden: KITLV Press, 2013).

${ }^{37}$ Jean Gelman Taylor, Indonesia: Peoples and Histories (London: Yale University Press, 2003), 110.

38 Steenbrink, "The Study of Comparative Religion by Indonesian Muslims."

39 See: Muhammad bin 'Abd al-Karīm Al-Syahrastānī, Al-Milal Wa Al-Niḥal (Beirut: Dār al-Fikr, 1968).

${ }^{40}$ See: Abū Syakūr Al-Sālimī, Al-Tamhīd Fì Bayān Al-Tauḥ̂̀d, ed. Omūr Tūrkmen (Istanbul: Markaz al-Buhūìs al-Islāmiyyah, 2017).

${ }^{41}$ Steenbrink, "The Study of Comparative Religion by Indonesian Muslims."
} 
This book was unlike the work of Shahrastani because Nuruddin has given a much simple description of the messages, although it was valuable for the Muslims of Aceh at the time in understanding religious history. The other work of Nuruddin was Asrar al-Insan fi Ma'rifat al-Ruh wa al-Rahman, talks about the idea of spirit which he discussed in more theologically on the meaning of the title spirit, Ruh, for Jesus as well as the meaning of other magnificent attributes for him; word of God or kalima, Messias and the light or nur. ${ }^{42}$

The rest of Nuruddin al-Raniri's life was spent in his home town Gujarat and he died in Rander 1658 CE. The major problem he faced in Aceh after the death of Sultan Iskandar Thani in February $1641 \mathrm{CE}$, the Sultan's wife succeed the position that was a time when Nuruddin should return to Gujarat. In the beginning of the Sultana's order, Nuruddin remained as the Muslim scholar of the time hence he was able to write Akbar al-Akhirah fi Ahwal al-Qiyamah (the Afterlife and the Day of Judgment) this work was also translated into many Indonesian languages. ${ }^{43}$

In 1643 CE, a Minangkabau scholar Saif al-Riyal has returned from his study at Surat, he was also known as a student of Sheikh Jamal al-Din who executed by Nuruddin's behest during the patronage of Sultan Iskandar Thani. Finally Saif al-Riyal gained the position of Sheikh al-Islam substituted of Nuruddin al-Raniri. He left Aceh with the unfinished work on Islamic Mysticism Jawahir al-Ulam fi Kasfh al-Ma'lum which latterly was completed by his student Abdurrauf Singkil who was also replaced Saif alRiyal as Sheikh al-Islam in 1661 CE. ${ }^{44}$

There was another work presented in the Sultanate of Aceh which in addition to the work of Nuruddin al-Raniri or inspired by Bustan al-Salatin, some of them was translated into local languages such as Tāj al-Salatținn (the Crown of the Kings), it was adapted from Persian sources during 1602-1603 CE. The passage contained an orthodox teaching of man and God, including various advices on various aspects of statecraft. The other religious texts were also written in the Indonesian versions, for instance the Quranic commentaries and works of Jurisprudence, some Islamic stories like 'Hikayat Iskandar Dzulkarnain' (the Story of Alexander the Two-horned) and the Hikayat Amir Hamzah (the Story of Amir Hamzah) was a romantic story based on Persian legends concerning the uncle of Prophet Muhammad Peace be upon Him. ${ }^{45}$

'Serat Centhini' (the message of Centhini) was another outstanding work in the nineteenth century CE Indonesia, it was also fascinating from the viewpoint of comparative religions. It was a longest poem written in Javanese language by a small team instructed by the crown prince of Surakarta kingdom evidently in the beginning of nineteenth century CE. It contained 150,000 lines or 12 huge volumes, the text emphasized on the internal varieties and even conflicts within the Muslim community, moreover it also mentioned the last Buddhist and Hindu heremites in region. ${ }^{46}$

${ }^{42}$ Ibid.

${ }^{43}$ Gibson, Islamic Narrative and Authority in Southeast Asia: From the 16th Century to the 21st Century.

${ }^{44}$ Ibid.

${ }^{45}$ Ricklefs, A History of Modern Indonesia since c. 1300-Present.

${ }^{46}$ Steenbrink, "The Study of Comparative Religion by Indonesian Muslims." 
Another work of nineteenth century CE was endeavored by Haji Hasan Mustafa, a religious scholar of West Java and a local companion of Snouck Hurgronje (Christian Snouck Hurgronje (1857-1936 CE) was a Dutch scholar of Oriental cultures and languages and Advisor on Native Affairs to the colonial government of the Netherlands East Indies, he was very famous among Indonesian scholars for his ideas concern on Islam especially in Aceh). During his research on Islam in Java from 1889 to 1893 CE, Haji Hasan Mustafa who probably was requested by the Dutch, he wrote an extensive work about Islam, customs, and tradition in West Java which was published in 1913 CE in Sundanese language of West Java. It was translated into Dutch entitled Gewoonten and Gebruiken der Soendaneezen published in 1966 CE. ${ }^{47}$

\section{CONCLUSIONS}

The presence of religious educational institution around sixteenth century Indonesia particularly in the form of Pesantren has signified that the practice of knowledge transformation has already emerged. Furthermore the main indication of knowledge and Intellectual achievement in that period was the existence of great muslim scholars who were supported by the muslim Sultans in various kingdoms around the archipelago. Primary their contributions were in the study of Tașawwuf (Islamic mysticism) in which they expounded the ideas and thought through several literary works.

The early muslim scholars who worked on this matter were such as; first was Hamzah Pansuri (d. 1527 CE), Syamsuddin of Pasai (d. 1630 CE), 'Abd al-Rauf b. Ali alJawi al-Fansuri al-Singkili was (born in 1615 CE), Sheikh Yusuf Makassar, 'Abd al-Samad ibn 'Abd Allah (d. 1800 CE), Muhammad Nafis ibn Idris ibn Husayn al-Banjari, and Nawawi al-Bantani.

Whereas the study of religions around seventeenth century in archipelago was done by Nuruddin al Raniri (d. 1658 CE), His contribution in the study of religions was partly written in Bustān al-Salāținn which talked regarding the tracts against Jews and Christians, some arguments on Torah and Bible that both were considered as forgeries. In other subjects, Al-Raniri was also wrote 'the Proof of the Truthful in the Refutation of the Heretics' a polemical attack on the works of Hamzah Fansuri and Syamsuddin of Pasai. Moreover, an encyclopedic work of Bustān al-Saläțin (the Garden of the Kings) was also done by him. There was another work presented in the Sultanate of Aceh which in addition to the work of Nuruddin al-Raniri or inspired by Bustān al-Salāțīn, some of them was translated into local languages such as Täj al-Salātīn (the Crown of the Kings), it was adapted from Persian sources during 1602-1603 CE.

In Java, 'Serat Centhini' (the message of Centhini) was another outstanding work in the nineteenth century $\mathrm{CE}$, it was also fascinating from the viewpoint of comparative religions. Another work was attempted by Haji Hasan Mustafa such as an extensive

\footnotetext{
${ }^{47}$ Ibid.
} 
work about Islam, customs, and tradition in West Java which was published in 1913 CE in Sundanese language of West Java.

This evidence gives us both pictures on religious study and the study of religions before twentieth century CE in the hand of Indonesian Archipelago muslim scholars. However, these works were such an overture for contemporary Indonesian Muslims to sincerely endeavor in religious study and the study of religions which contemporary became popular among the Muslim students.

\section{REFERENCES}

Al-Attas, Syed Muhammad Naquib. Islam Dalam Sejarah Dan Kebudayaan Melayu. Kuala Lumpur: ABIM, 1972.

Al-Ghazālī, Abū Ḥamid. Al-Tỉbr Al-Masbūk Fi Nașīhat Al-Mulūk. Edited by Aḥmad Syams al-Dīn. Beirut: Dār al-Kutub al-'Ilmiyyah, 1988.

Al-Sālimī, Abū Syakūr. Al-Tamhīd Fì Bayān Al-Tauhìd. Edited by Omūr Tūrkmen. Istanbul: Markaz al-Buhūì al-Islāmiyyah, 2017.

Al-Syahrastānī, Muhammad bin 'Abd al-Karīm. Al-Milal Wa Al-Nihal. Beirut: Dār alFikr, 1968.

Brown, Colin. A Short History of Indonesia: The Unlikely Nation? New South Wales: Allen \& Unwin, 2003.

Cribb, Robert, and Audrey Kahin. Historical Dictionary of Indonesia. Second. Maryland: Scarecrow Press, Inc., 2004.

Dahlan, Abdul Aziz. "Tasawuf Syamsuddin Sumatrani." IAIN Syarif Hidayatullah, 1992.

Dhofier, Zamakhsyari. "The Pesantren Tradition: A Study of the Role of the Kyai in the Maintenance of the Traditional Ideology of Islam in Java." The Australian National University, 1980.

Gibson, Thomas. Islamic Narrative and Authority in Southeast Asia: From the 16th Century to the 21st Century. New York: Palgrave Macmillan, 2007.

Hadi, Amirul. Islam and State in Sumatra: A Study of Seventeenth-Century Aceh. Leiden: Brill, n.d.

Hadi, Amirul. Islam and State in Sumatra: A Study of Seventeenth-Century Aceh. Leiden: Brill, 2003.

Hamid, Abu. Syekh Yusuf Makassar: Seorang Ulama, Sufi Dan Pejuang. Indonesia, Jakarta: Yayasan Obor Indonesia, 1994.

Howell, Julia Day. "Sufism and the Indonesian: Islamic Revival." The Journal of Asian Studies 60, no. 3 (2001).

K. S. Nathan, and Muhammad Hashim Kamali. Islam in Southeast Asia: Political, Social, and Strategic Challenges for the 21st Century. Singapore: ISEAS, 2006. 
Laffan, Michael. The Bustan Al-Salatin Nuruddin Ar-Raniri: Reflections on Cultural Role of Foreign Abroad in the Malay World in the Sixteenth Century. Leiden: KITLV Press, 2013.

Lukens-Bull, Ronald. A Peaceful Jihad: Negotiating Identity and Modernity in Muslim Java. New York: Palgrave Macmillan, 2005.

Mulyati, Sri. "Sufism in Indonesia: An Analysis of Nawawi Al-Banteni's Salalim AlFudala'." McGill University, 1992.

Muthalib, Abdul. "The Mystical Thought of Muhammad Nafis Al-Banjari: An Indonesian Sufi of the Eighteenth Century." McGill University, 1995.

Ricklefs, M C. A History of Modern Indonesia since c. 1300-Present. 3rd ed. London: Palgrave Macmillan, 1981.

Steenbrink, Karel A. “The Study of Comparative Religion by Indonesian Muslims.” Numen 37, no. 2 (1990).

Taylor, Jean Gelman. Indonesia: Peoples and Histories. London: Yale University Press, 2003. 
Alfina Hidayah, Hamdan Maghribi 